IRA-International Journal of Management \& Social Sciences

ISSN 2455-2267; Vol.07, Issue 02 (2017)

Pg. no. 232-243

Institute of Research Advances

http://research-advances.org/index.php/RAJMSS

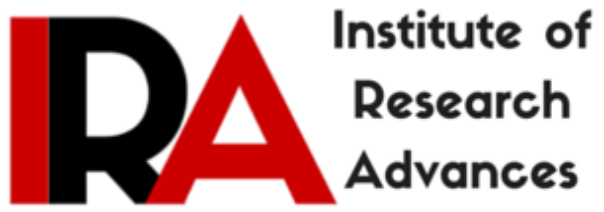

\title{
An Examination of the Mediating Role of Employees' Job Satisfaction on the Relations between the Work Motivation, Leadership Style, Competence and Employees' Performance
}

\author{
Lusman Mansyur ${ }^{1}$, Jeni Kamase ${ }^{2}$, Syahrir Mallongi ${ }^{3}$, Lukman Chalid ${ }^{4}$ \\ ${ }^{1}$ Doctoral Student in Faculty of Economics, Muslim University of Indonesia, Indonesia. \\ ${ }^{2,3,4}$ Faculty of Economics, Muslim University of Indonesia, Indonesia.
}

Type of Review: Peer Reviewed.

DOI: http://dx.doi.org/10.21013/jmss.v7.n2.p13

\section{How to cite this paper:}

Mansyur, L., Kamase, J., Mallongi, S., \& Chalid, L. (2017). An Examination of the Mediating Role of Employees' Job Satisfaction on the Relations between the Work Motivation, Leadership Style, Competence and Employees' Performance. IRA-International Journal of Management \& Social Sciences (ISSN 2455-2267), 7(2), 232-243. doi:http://dx.doi.org/10.21013/jmss.v7.n2.p13

(C) Institute of Research Advances

\section{$(\mathrm{cc})$ EY-NC}

This work is licensed under a Creative Commons Attribution-Non Commercial 4.0 International License subject to proper citation to the publication source of the work.

Disclaimer: The scholarly papers as reviewed and published by the Institute of Research Advances (IRA) are the views and opinions of their respective authors and are not the views or opinions of the IRA. The IRA disclaims of any harm or loss caused due to the published content to any party. 


\begin{abstract}
The purpose of this study was to analyze the direct influence of work motivation, leadership style and competence on job satisfaction, and the same direct influence on employee performance, analyze the direct effect of job satisfaction on the performance and analyze the influence not directly work motivation, leadership style and competence through job satisfaction on employee performance. This study has performed on the Regional office of Kopertis IX Sulawesi using 125 employees as a sample. The Data from the questionnaires were analyzed using Structural Equation Model using AMOS assistance 18. The study found that work motivation is a negative and significant effect on job satisfaction. Application of motivation in the form of existence, connectivity and growth is still low, but the motivation needed to improve employee satisfaction. Competence is a positive and insignificant effect on employee performance. Employee competence is still not oriented towards the innovation and technology in influencing employee performance improvement. Competence is a positive and insignificant effect through job satisfaction on employee performance. Competence practice adapted to the needs of work at the moment, these conditions have an impact on the low level of job satisfaction perceived by employees so that the cause of employee performance
\end{abstract}

Keywords: Work motivation, leadership style, competence, job satisfaction, employees' performance

\title{
Introduction
}

Indonesian republic has a purpose as stated in the Preamble of the Constitution of the Republic of Indonesia Year 1945, namely to protect the entire Indonesian nation and the entire homeland of Indonesia and to promote the general welfare, educating the nation and participate in the establishment of world order based on freedom, peace eternal, and social justice.Realizing the objectives of Article 31 (3) of the Constitution of the Republic of Indonesia Year 1945 mandates that the Government shall manage and organize a national education system that enhances faith and devotion to God Almighty and good character in order to achieve the nation organized in the enactment Act. In addition to Article 31 (5) instructs that the Government promote science and technology to uphold religious values and national unity for the progress of civilization and the welfare of humanity.

Education is a conscious and deliberate effort to create an atmosphere of learning and the learning process so that learners are actively developing the potential for him to have the spiritual power of religion, selfcontrol, personality, intelligence, morality noble, as well as the skills needed him, the people of the nation and the state (The Law of the Republic of Indonesia Number 20/2003 on the System of Education). Private High Education Coordinator has called KOPERTIS is an institution whose main duty as supervisors, controllers and Trustees of Private colleges exist within its territory and are required to carry out the main task in fostering college grade and quality, because based on experience and the demands of college then Kopertis committed to improving service and always strive to improve the existing human resources in it. This is what requires Kopertis to implement the system as well as providers of human resource personnel to realize the objectives of the organization.

Upon consideration of this, it issued Regulation of the Minister of Education and Culture of the Republic of Indonesia No. 1 of 2013 on the Organization and Work Procedure of Private Higher Education Coordinating, in this regulation mentioned Private High Education Coordinatoris executing tasks in the field of monitoring, control, and college coaching in a region led by a coordinator who is under and is responsible to the Minister of Education and Culture, in carrying out everyday tasks Coordinator is 
responsible to the Director General of higher Education, Job Coordinator occupied by a senior lecturer with the status of civil servants civilian of one of the colleges that have certain qualifications.

Facing the challenges and job competition intensifies, the existence of human resources becomes important and needed to be managed and utilized in achieving organizational goals. Momentum is important from the application of human resource management is to make every employee in an organization is able to carry out the vision, mission, duties and functions and values espoused by an organization to grow and progress. On this basis, the application of human resource management becomes urgent and relevant to be considered and developed in order to realize the objectives of the organization. This becomes important and necessary for Regional Coordinator of Private Universities Kopertis IX Sulawesi to implement human resource management as an important momentum in managing and using employees as human resources.

Realizing it is not easy, because it must be performed by employees who have performed. The fact seen as a factual phenomenon shows that the achievement of the performance of employees within the last five years has not been realized in accordance with expectations. In the last five years according to a report of information part of human resource development indicates that the staff of the Regional Coordinator of Private Universities Kopertis IX Sulawesi realization achievement of performance that does not achieve the expected target. More details are shown in Table 1:

Table 1. employees' performance at the Office Regional Kopertis IX Sulawesi

\begin{tabular}{|c|c|c|}
\hline \multirow{2}{*}{ Year } & \multicolumn{2}{|c|}{ employee performance } \\
\cline { 2 - 3 } & Actual (percentage) & Target (percentage) \\
\hline 2012 & $87.5>$ & 90 \\
\hline 2013 & $86.6>$ & 90 \\
\hline 2014 & $85.3>$ & 90 \\
\hline 2015 & $72.0>$ & 90 \\
\hline 2016 & $64.5>$ & 90 \\
\hline
\end{tabular}

Source: Regional office, Kopertis IX Sulawesi (2017)

According to the table above, the determination target $>90 \%$ determined by the value of the achievements of activities monitoring, control and development (WASDALBIN) stated criteria above 90 up to reach the target and under 90 expressed yet reached the target, The percentage of employee performance changes up and down based on performance as the main tasks and functions achieved in 2012 realized by $87.5 \%$ decreased to $64.5 \%$ in 2016 and did not reach the target of > 90\%.Understanding the achievement appraisal employee performance declines, the consideration to be raised in the realization of employee performance through improvements in the quantity, quality, efficiency, effectiveness and employee loyalty in carrying out duties and functions that demand professionalism optimal work. As seen in everyday reality, that there is an employee in the line of duty is always to select the work in accordance with the will; while demanding organizations to provide services that many optimally.

The implementation of the tasks performed by employees often complain about the Kopertis as inferior (quality) of the aspects of the presentation of improper work time (efficient), not oriented to benefit the activities of the service provided (effective) and officers often do not obey the leadership and organizations providing services in showing loyalty. On this fact, it is necessary to consider reorganizing and improving employee performance through the application of the theory of employment targets. The success of an organization in achieving its objectives judged from the employee's performance results. Employee performance evaluation measured quantity, quality, efficiency, effectiveness and loyalty as demanded by the organization and policy management (Dessler, 2013: 66). 
Decrease in employee performance cannot be separated from the contribution of perceived job satisfaction in carrying out the duties and functions of the employment. A growing phenomenon in the regional office Kopertis IX Sulawesi, that the difficult improving employee performance when it is not supported with the job satisfaction. It is relevant to what is proposed (Rivai and Sedarmayanti, 2008: 96) that the achievement of employee performance easily realized by first realizing job satisfaction. This does not correspond with the reality, where employees often complain, expressed disappointment and less concerned with the execution of their duties and functions. The reason often cited by employees for work satisfaction is not met. There are several considerations that lead to employee satisfaction is not met, among others, an employee works less please work it faces every day, less than happy with the challenges of work, cannot be accomplished, low compensation and promotion is often postponed.

This fact affects the work carried out both individually and collectively. Symptoms shown as lazy, so much work abandoned and overlap; less innovative because it does not dare to make a breakthrough in the face of the challenges of work; tend to do a monotonous job, so do not perform; always judge the work based on the amount of compensations on the compensation and employee well competed for the attention of the leadership to be promoted not based on merit. The following data show employee satisfaction at the regional office, Kopertis IX Sulawesi in Table 2:

Table 2. Employee Job Satisfaction at the regional office, Kopertis IX Sulawesi

\begin{tabular}{|c|c|c|}
\hline \multirow{2}{*}{ Year\% } & \multicolumn{2}{|c|}{ Job Satisfaction } \\
\cline { 2 - 3 } & Actual (percentage) & Target (percentage) \\
\hline 2012 & $89.5>$ & 90 \\
\hline 2013 & $85.6>$ & 90 \\
\hline 2014 & $83.5>$ & 90 \\
\hline 2015 & $82.8>$ & 90 \\
\hline 2016 & $77.9>$ & 90 \\
\hline
\end{tabular}

Source: regional office, Kopertis IX Sulawesi, (2017)

Based on the results of the evaluation team individual job satisfaction of employees indicate the realization of job satisfaction that is achieved from the activities of completion of work of individual employees has decreased from 89.5 percentage in 2012 to 77.9 percentage in 2016. Data last of the five years have not reached the target satisfaction > 90percentage. The decrease in the level of job satisfaction felt by employees, of these things into consideration to be addressed and corrected by considering the theory of maintenance or $\mathrm{X}$ and $\mathrm{Y}$ that each individual in job satisfaction is always confronted by the results satisfactory and unsatisfactory. Both of these factors to be important in determining the results of the work produced satisfied or not. In order to achieve job satisfaction should provide a boost to please exciting work, a dynamic labor challenges, and the embodiment of work performance, higher compensation and promotions eligibility (Herzberg in Rivai, 2008: 55).

Understanding the low job satisfaction and impact on the performance of employees, this happens because there are direct effects related to work motivation, leadership style and competence of employees in carrying out their duties and functions, thus providing the effect of directly or indirectly to job satisfaction and the performance of employees. Assessment of the performance of employees who did not reach the expected target to be related to some previous studies showing that the decline in performance is influenced by job satisfaction, motivation, leadership and competence. The study recommends that the motivation and competence positive effect on performance (Nuraeni, 2011). Similar findings also provide evidence that the motivation positive and significant impact on job satisfaction and performance (Achmad Gani, 2006). 
Furthermore, associated with several previous studies that examined the causes of low satisfaction performance is not increasing, among others, research, previous research findings prove that employee motivation direct and significant impact on job satisfaction (Mursalim Umar Gani, 2005). Motivation and competence has a negative and significant effect on job satisfaction and performance (Charles, 2011). Low job satisfaction and decreasing the achievement of the performance of employees that occurred during this in regional office Kopertis IX Sulawesi, is inseparable from the influence of work motivation Low employee influence on job satisfaction and employee performance. Employee as a human being in work requires enthusiasm, encouragement and support to always be consistent, can relate to and grow or develop. Facts on the ground show that employees are less motivated because of the necessities of life, physical, their families have not been fulfilled, social needs for interaction as a representation of their interacting unmet needs, and the unmet needs of the job, so the productivity and creativity of their work is low. This is the cause of low motivation to work of employees, so employees have not been in line with expectations feel satisfaction in their work and the impact on their poor performance as employees.

Understanding the low motivation to work on job satisfaction and employee performance, then the leaders, need to implement the ERG theory put forward Clayton Alderfer, that every person needs motivation to meet the needs of existence, relationship and growth is commonly called necessity ERG. ERG element covers the demands of subsistence, physical needs, family needs, social needs, the need for jobs and the needs of productive and creative (Hersey, 2012: 67). The previous study that examines the influence of motivation on job satisfaction and performance, the results showed a positive and significant effect of motivation on employee performance through job satisfaction (Mohamad Zaid, 2014). Other evidence indicates that the indirect negative motivation and no significant effect on job satisfaction (Moyosola, 2014).

Moreover, job satisfaction and low performance cannot be separated from the influence of leadership style exhibited by employees in carrying out their duties and functions. where an employee in the show transactional leadership not to implement a reward depending on the result of work accomplished, not exercise leadership exception management actively by inviting each subordinate to maintain the rules and standards of work that has been agreed, not implement exception management passively participated in carrying out the work along with his subordinates, and do not apply the principle of laissez-faire to abdicate responsibility by providing authority to subordinates to make decisions. Subordinates have often protested, complained even ignore transactional leadership styles given to the subordinates. The result is many of the subordinates who are not satisfied in the work that led to lower work satisfaction and achievement of the performance decline.

One of the causes of job satisfaction and performance declines due to problems styles of leadership are not actualized properly within an organization. Where the leadership of the organization is not able to demonstrate transactional leadership that led to his subordinates receive transactional leadership of the well, so that subordinates easily led, driven and influenced together in realizing the objectives of the organization (Wiwiek, (2013). Addressing the leadership style that caused satisfaction and employee performance decline, because the management in the scope of regional office Kopertis IX Sulawesi less attention to the application of leadership style are good, so it is necessary to apply the theory of the characteristics of transactional leadership, that every leader must be able to exchange in the influence and mobilize subordinates to run the leadership characteristics well. that is, leaders give orders or directives to his subordinates in accordance with the right people to carry out job leads, so the consideration for the transaction conducted between leaders and subordinates (Bass 2010: 125).

Assessment of the low transactional leadership influence on satisfaction and performance has associated with previous research, that the application of transactional leadership that does not comply with the basic styles shown result in decreased job satisfaction and performance of human resources (Wiwiek, 2013). 
Other researcher (Nasrin, 2010) recommends that job satisfaction and performance be determined by the application of leadership that provides a positive and significant effect.

Also visible from the fact that is found in the daily activities of employees, namely regarding the competence of employees that showed that employees often ask or propose to the leaders to get a policy in order to realize an increase in the competence of job satisfaction and improved employee performance. Understanding the phenomenon is based on facts about the competency of employees at this time, shows that the competence of employees need to be improved, given the employee has the duties and functions in developing education and training are expected to know, skillful, controlled and reliable in work. The fact that occur due to the low competency work activity often causes delays, no timely serving, often numerous errors and long service process. This is because the competency of lower-level officials. Employee aware of the competencies they have, so it is often suggested to the leadership to be given the opportunity to increase their knowledge, skills, mastery and work experience to improve their competence. Servants often suggested following the leaders to give formal education opportunities to pursue higher education, for example following the graduate program or postgraduate program. Nevertheless, it is not given to follow the policy by the leadership of higher education.

Employee desiring to be included in a variety of educational programs and research, both are structural, functional and technical, but in reality for reasons of budgetary constraints, there are many employees who have never attended education and training programs. Including employees often proposing to follow various courses oriented quality improvement work such as treasury courses, languages, computers, archives and assets, due to budget constraints, employees usually carry their own and it is only limited to doing. Including lack of work experience, a regular employee proposes to do transfer or rotation of the workplace in order to improve the competence of employees.

This fact in its application to experience the difference between facts and circumstances of the case, because it should be considered to improve and enhance the competence of employees through a system of competency-based organizational work. This system refers to the theory that introduced competency assessment (McKenna, 2010: 189) that everyone in the organization has an interest in achieving the appropriate knowledge, skills, work experience and attitude of mastering which is called the competence to achieve organizational goals. The previous study that examines the effect of competence on job satisfaction and performance, that competence positive and significant effect on performance (Mohammad Shahosein, 2012). Similar fact, which the competence is directly positively and significantly to performance, but indirectly competence through job satisfaction and a significant negative effect (Soleiman, 2012).

\section{Literature Review and Hypothesis testing}

In this study, there are five variables were observed consisting of the three exogenous variables and two endogenous variables. An exogenous variable in this study consists of motivation, competence and commitment to the organization. While the endogenous variables in the form of a variable between that job satisfaction and the dependent variable is the performance.

\section{Work motivation}

The concept of motivation refers to the ERG theory as a foundation that is used to understand the motivation of someone who encouraged, supported and encouraged to have an existence in creating a relationship to grow or develop in carrying out his or her work activities. Understanding the needs of the ERG theory, there are three important bases to see how people are motivated because of the encouragement or desire fulfilled his personal needs. The third cornerstone is focused on: 1) the need for the existence of self is to develop all its potential to meet the primary needs, (need for existence); 2) the need for interaction is the need to socialize and interact with people and the work environment (need relations); and 3) the need for growth (need growth) is the need to maintain the achievements of the work and recognition of the work produced (Hersey, 2011: 69). 
$\mathrm{H}_{1} \quad$ Work motivation is positively related toemployees' job satisfaction.

\section{Leadership Style}

Transactional leadership style includes three dimensions: first, contingent reward to influence the leaders clarify the work to be done, using incentives as a tool to encourage the achievement of the results of the implementation of tasks as expected. Second, management by exception, which consists of two that is passive, to influence the behavior of leaders and use the efforts of correction or punishment as a response to the poor performance / deviations to standards, and actively to influence behavior, leaders actively monitoring the work of the employees and the use of corrective efforts in order to ensure that the work is done and completed according to the standard. Third, laissez-faire leadership, the leader who avoid effort to influence subordinates, dereliction of duty, coaching as a leadership, immersed him in the work routine and avoid confrontation. Leadership responsibilities to subordinates, does not set a clear goal, not help the decision-making group and let all flow during all looks safe (Bass, 2010: 122).

$\mathrm{H}_{2}$ Leadership style is positively related toemployees' job satisfaction.

\section{Competence}

Orientation of the quality of the individual competencies of human resources assessed from knowledge work is understood in accordance with the level of education you have, the skills of a wide range of education and training that followed, the experience of working life traversed and mastery of work based on persistence owned (Harry, 2011: 95), Elements that build competence in the form of job knowledge, skills, experience and attitude in the mastery of work. The higher a person's knowledge increasingly skilled labor in developing creative work according to level of experience and attitude control of the work area occupied (Gully, 2008: 71).

$\mathrm{H}_{3}$ Employees' competences are positively related toemployees' job satisfaction.

\section{Employees' Job Satisfaction and Employees' Performance}

Maintenance job satisfaction developed by an organization synonymous with the activity of choice were satisfied that the work is interesting, satisfied with the work challenges faced, satisfied as a result of achievement, satisfaction of getting an award of recognition of the work and satisfied in taking responsibility work (Luthans, 2007: 119). A group of observers of human resource management to create a research program related to the general problem regarding job satisfaction. Theory of Satisfied used as the program develops a conceptual framework, to create job satisfaction indicators, including job satisfaction in the form of interest; The fundamental satisfaction in the challenges of the job; satisfaction with the achievements of the plume; appropriateness of compensation; and the satisfaction of promotion (Hersey, 2007: 45)

Performance is defined as the record of the outcomes produced on a specified job function or activity during periods (Bernardin and Russel; in Ruky, 2012: 28). A similar view describes the performance as a result of the implementation level of achievement of certain tasks. Performance management is the overall activities undertaken to improve organizational performance, including the performance of individuals and work groups. Understanding the performance contains substances work by a person's achievement. Performance is a reflection of the results achieved by a person or group of people. The individual performance (individual performance) with the performance of institutions (institutional performance) there is a close relationship. If the employee's performance (individual performance) better than most likely performance of institutions (institutional performance) is also good (Simanjuntak, 2005).

$\mathrm{H}_{4}$ Work motivation is positively related to employees' performance.

$\mathrm{H}_{5}$ Leadership style is positively related to employees' performance.

$\mathrm{H}_{6} \quad$ Employees' competence is positively related to employees' performance.

$\mathrm{H}_{7}$ Employees' job satisfaction is positively related to employees' performance. 
$\mathrm{H}_{8}$ Employees' job satisfaction mediates the relations between work motivation and employees' performance.

$\mathrm{H}_{9}$ Employees' job satisfaction mediates the relations between leadership style and employees' performance.

$\mathrm{H}_{10}$ Employees' job satisfaction mediates the relations between employees' competence and employees' performance.

\section{Methods}

This study was designed to address problems that have been formulated and the goals to be achieved and to test the hypothesis. The type of data in this study consisted of primary and secondary data. Primary data is data obtained from the results of questionnaires and interviews. Secondary data is data obtained at the Office of Regional Kopertis IX Sulawesi. Sources of data obtained from the parties associated with this research. The population in this study was all employees of the Office of Regional Kopertis IX Sulawesi taken purposively based on positions held. The sampling technique used total sampling method with the same sample set with the number of population is taken purposively based on job title. Therefore, the sample size in this study was 125 respondents. Data analysis techniques used in explaining the phenomenon in this research is descriptive statistical analysis techniques and analysis of Structural Equation Modeling (SEM).

\section{Analysis and Discussion}

Based on the method of determining the value of the model, the first model testing variables are grouped into exogenous variablesand endogenous variables. An exogenous variable is a variable whose value is determined outside the model. While the endogenous variable is a variable, whose value is determined by an equation or model relationship is formed. Included in this group of exogenous variables is the measurement of work motivation, leadership style and competence, while those classified, as an endogenous variable is job satisfaction and employee performance. The model is said to be good when the hypothetical theoretical model development supported by empirical data. The result of SEM analysis is complete can be seen in the following figure:

Figure 1. Initial model

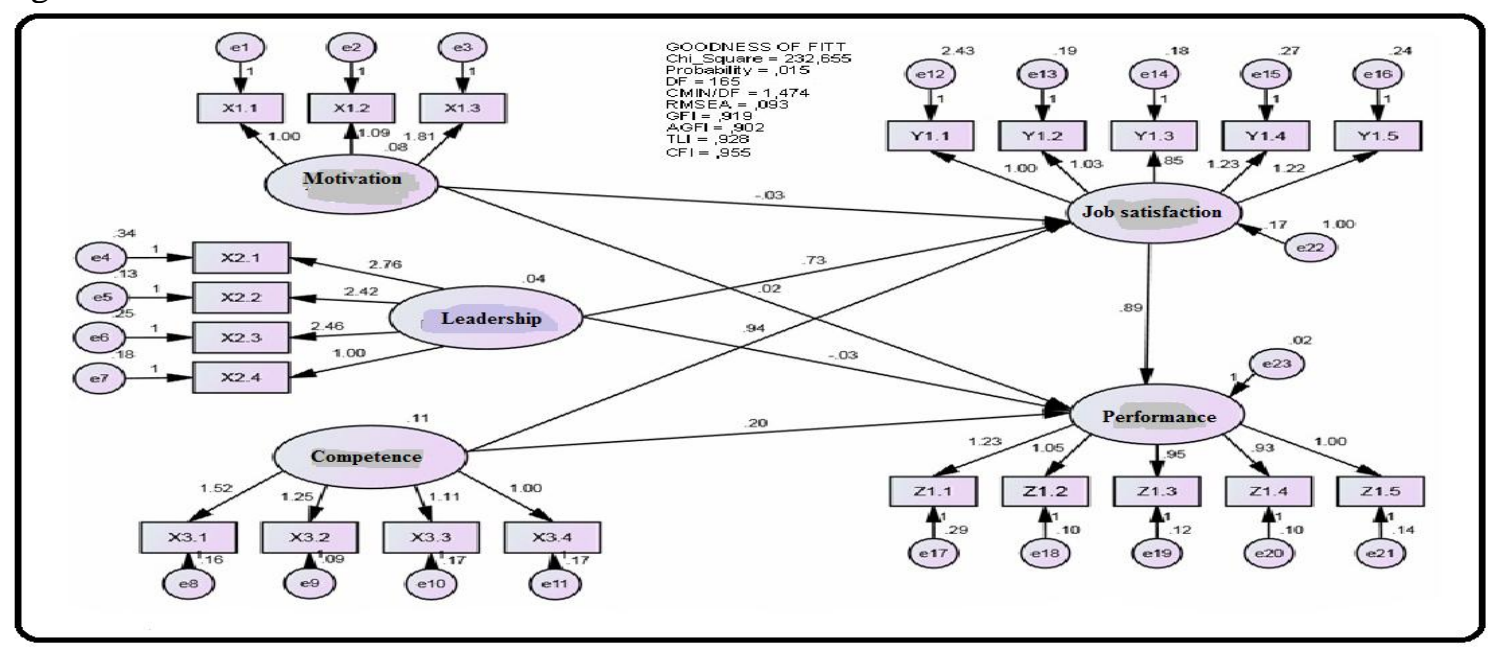

Evaluation models suggest eight criteria of goodness of fit indices seen the value of chi-square still great and seemingly some of the criteria are not in accordance with thevalues cutoff were determined, so that a modification of the model by performing the correlation between the error indicator in accordance with the instructions of the modification indices. The results of the analysis after the final model obtained are as follows: 
Figure 2. The final model

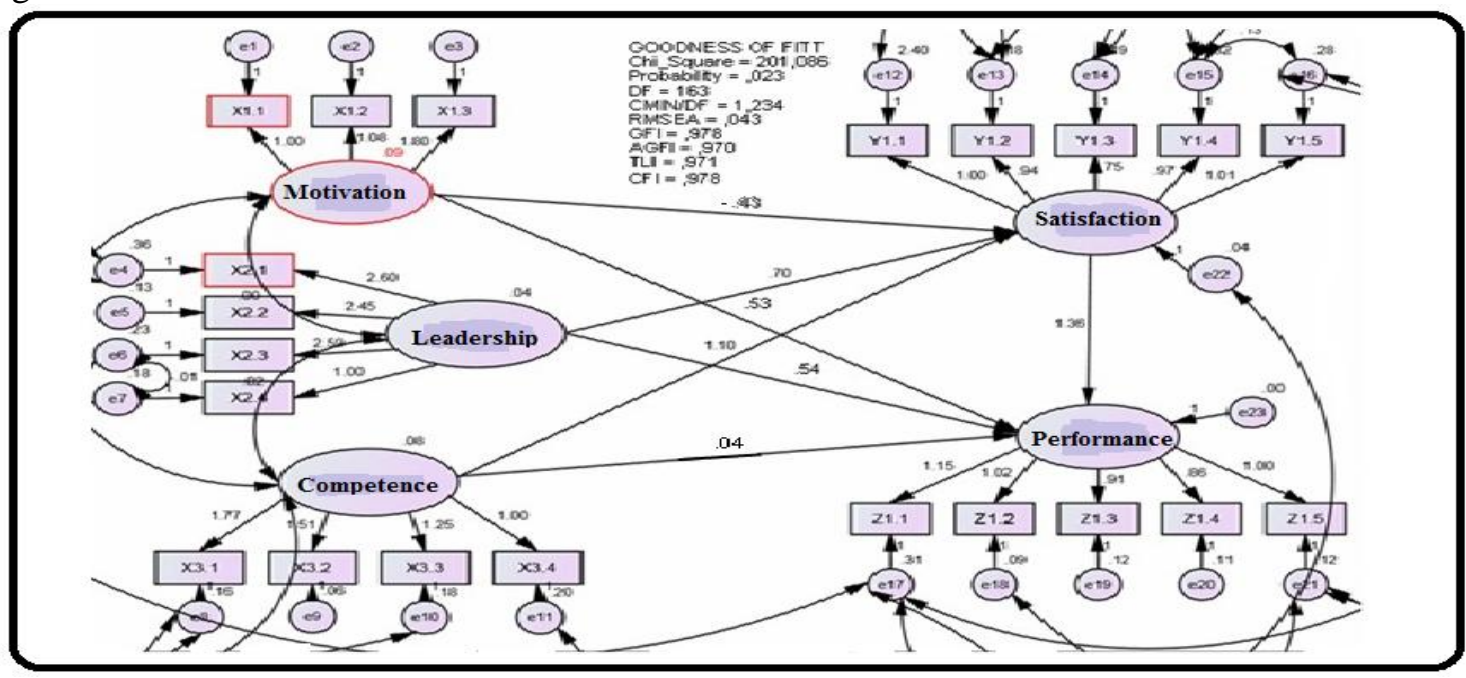

Model test results are presented in Figure 2 in an evaluation based on the goodness of fit indices in Table 3 below with the criteria presented models as well as critical values that have compatibility data.

Table 3. Evaluation criteria Goodness of Fit Indices Overall Model

\begin{tabular}{|c|c|c|c|c|c|}
\hline $\begin{array}{c}\text { Goodness of } \\
\text { fit index }\end{array}$ & Cut-off Value & Initial stage & $\begin{array}{c}\text { Annotatio } \\
\mathbf{n}\end{array}$ & Final Stage & Annotation \\
\hline Chi_Square & $\begin{array}{c}<232,655 \\
\text { (Initial) and } \\
<201,086 \\
\text { (Final) }\end{array}$ & 212,670 & good & 175,555 & good \\
\hline Probability & $\geq 0.05$ & 0,015 & good & 0.023 & good \\
\hline CMIN/DF & $\leq 2.00$ & 1,474 & good & 1,234 & good \\
\hline RMSEA & $\leq 0.08$ & 0,093 & Marginal & 0.043 & good \\
\hline GFI & $\geq 0.90$ & 0,919 & good & 0.978 & good \\
\hline AGFI & $\geq 0.90$ & 0,902 & good & 0.970 & good \\
\hline TLI & $\geq 0.94$ & 0,928 & Marginal & 0,971 & good \\
\hline CFI & $\geq 0.94$ & 0,955 & good & 0.978 & good \\
\hline
\end{tabular}

Source: Data after the processed

Results of the evaluation model for early stage shows of the eight criteria of goodness of fit indices only six who had been eligible cut-off value, the Chi-square, probability, CMIN / DF, GFI, AGFI and CFI, so be modified model fits with hints of modification indices. After the modification of the model, then at the final stage indicates there are six criteria for goodness of fit indices have met the criteria or match the criteria of a cut-off value, so that the model can be said to have been in accordance with the criteria of goodness of fit indices for analysis. Based on empirical models proposed in this study can be tested 
against the hypothesis put forward by testing the path coefficients in structural equation modeling. Table 4 is a hypothesis by looking at the p-value, if the p-value less than 0.05 then the relationship between significant variables. It also describes the direct effect means that there are positive influence directly between variables, the indirect effect means that there are positive influence indirectly between variables, and the total effect is the accumulation of direct influence and indirectly.

Overall model showing there are seven models of direct influence and three hypothesized indirect effect. Analysis of the direct effect, indirect effect and the total effects between variables in the model, was used to compare the effect of each variable constructs. The direct effect is the coefficient of all coefficients lines with arrows one end, while the indirect effect is an effect that arises through an intervening variable, while the total effect is the effect of the various relationships (Ferdinand, 2000: 139). Results of testing the influence of variables in Table 2 shows the influence of the direct, indirect and total influence between variables, which can be explained as follows:

Table 4. Hypothesis Testing Direct and Indirect Effect

\begin{tabular}{|c|c|c|c|c|c|c|c|c|}
\hline \multirow[b]{2}{*}{$\begin{array}{l}\text { Hypothesis } \\
\text { Number }\end{array}$} & \multirow[b]{2}{*}{ Exogenous } & \multirow[b]{2}{*}{ Intervening } & \multirow[b]{2}{*}{ endogenous } & \multicolumn{4}{|c|}{ Standardize } & \multirow[b]{2}{*}{ Description } \\
\hline & & & & Direct & Indirect & Total & $\begin{array}{c}\text { P- } \\
\text { Value }\end{array}$ & \\
\hline $\mathrm{H}_{1}$ & $\begin{array}{l}\text { Work } \\
\text { motivation }\end{array}$ & - & $\begin{array}{l}\text { Job } \\
\text { satisfaction }\end{array}$ & $\begin{array}{c}- \\
0,432 \\
\end{array}$ & - & $\begin{array}{c}- \\
0,432 \\
\end{array}$ & 0,038 & $\begin{array}{c}\text { negative } \\
\text { significant }\end{array}$ \\
\hline $\mathrm{H}_{2}$ & $\begin{array}{l}\text { Leadership } \\
\text { Style }\end{array}$ & - & $\begin{array}{l}\text { Job } \\
\text { satisfaction }\end{array}$ & 0,697 & - & 0,697 & 0,012 & $\begin{array}{c}\text { positive } \\
\text { significant }\end{array}$ \\
\hline $\mathrm{H}_{3}$ & Competence & - & $\begin{array}{l}\text { Job } \\
\text { satisfaction }\end{array}$ & 1,097 & - & 1,097 & 0,000 & $\begin{array}{c}\text { positive } \\
\text { significant }\end{array}$ \\
\hline $\mathrm{H}_{4}$ & $\begin{array}{l}\text { Work } \\
\text { motivation }\end{array}$ & - & $\begin{array}{l}\text { Employee } \\
\text { performance }\end{array}$ & 0,534 & - & 0,534 & 0,032 & $\begin{array}{c}\text { positive } \\
\text { significant }\end{array}$ \\
\hline $\mathrm{H}_{5}$ & $\begin{array}{l}\text { Leadership } \\
\text { Style }\end{array}$ & - & $\begin{array}{l}\text { Employee } \\
\text { performance }\end{array}$ & 0,540 & - & 0,540 & 0,033 & $\begin{array}{c}\text { positive } \\
\text { significant }\end{array}$ \\
\hline $\mathrm{H}_{6}$ & Competence & - & $\begin{array}{l}\text { Employee } \\
\text { performance }\end{array}$ & 0.037 & - & 0.037 & 0.215 & $\begin{array}{c}\text { positive } \\
\text { insignificant }\end{array}$ \\
\hline $\mathrm{H}_{7}$ & Job satisfaction & - & $\begin{array}{l}\text { Employee } \\
\text { performance }\end{array}$ & 1.360 & - & 1.360 & 0.000 & $\begin{array}{c}\text { positive } \\
\text { significant }\end{array}$ \\
\hline $\mathrm{H}_{8}$ & $\begin{array}{l}\text { Work } \\
\text { motivation }\end{array}$ & $\begin{array}{c}\text { Job } \\
\text { satisfaction }\end{array}$ & $\begin{array}{l}\text { Employee } \\
\text { performance }\end{array}$ & 0.534 & 0.498 & $1 .($ & 32 & $\begin{array}{c}\text { positive } \\
\text { significant }\end{array}$ \\
\hline $\mathrm{H}_{9}$ & $\begin{array}{l}\text { Leadership } \\
\text { Style }\end{array}$ & $\begin{array}{c}\text { Job } \\
\text { satisfaction }\end{array}$ & $\begin{array}{l}\text { Employee } \\
\text { performance }\end{array}$ & 0.540 & 0.577 & 1. & 117 & $\begin{array}{c}\text { positive } \\
\text { significant }\end{array}$ \\
\hline $\mathrm{H}_{10}$ & Competence & $\begin{array}{c}\text { Job } \\
\text { satisfaction }\end{array}$ & $\begin{array}{l}\text { Employee } \\
\text { performance }\end{array}$ & 0.037 & 0.049 & 0. & 86 & $\begin{array}{c}\text { positive } \\
\text { insignificant }\end{array}$ \\
\hline
\end{tabular}

Source: Data after the processed

1. Motivation has a negative and significant effect on job satisfaction with p-value $=0,038<0,05$ with a coefficient at $-0,432$, this coefficient indicates that the employee still has a low motivation to work, but it still makes the employees are satisfied in their work.

2. Leadership style has a positive and significant effect on job satisfaction and p-value $=0,012<$ 0,05 with a coefficient at $-0,697$, this coefficient indicates that the style of leadership that is owned by the leadership make employees satisfied in their work. 
3. Employee competency has a positive and significant effect on job satisfaction and $\mathrm{p}$-value $=$ $0,000<0,05$ with a coefficient value of 1,097 , this coefficient indicates that the competency of employees makes creating employee satisfaction in work.

4. Work motivation has a positive and significant effect on the performance of the p-value $=0,032<$ 0,05 with a coefficient value of 0,534 , this coefficient indicates that the high motivation made the employee performs well.

5. Leadership style has a positive and significant effect on the performance of the p-value $=0,033<$ 0,05 with a coefficient value of 0,540 , this coefficient indicates that leadership style makes creating employee performs well.

6. Competence has a positive and insignificant effect on employee performance with $p$-value $=0,215$ $>0,05$ with a coefficient of 0,037 , this coefficient indicates that although the employee has the competence, but it has not contributed to the improved performance of employees.

7. Job satisfaction has a positive and significant effect on employee performance with $\mathrm{p}$-value $=$ $0,000<0,05$ with a coefficient of 1,360 , this coefficient indicates that employees are satisfied with pekerjaaannya, thus affecting employee performance improvement.

8. Motivation to work through job satisfaction has a positive and significant effect on employee performance with a significant coefficient value of 0,498 , this coefficient indicates that employees are motivated improve employee performance, because employees are satisfied in their work.

9. Leadership style through job satisfaction has a positive and significant effect on employee performance with coefficient of 0,577 , the coefficient indicates that a good leadership style can further improve the perceived performance to match employee satisfaction at work.

10. Competence through job satisfaction has positive and insignificant effect on employee performance with coefficient of 0,049 , the coefficient indicates that the competency needs to be increased, thus increasing the employee performance through job satisfaction.

Based on these facts, it can be explained that:

$\mathrm{H}_{1}$ : Rejected by empirical data so that the research hypothesis which states that work motivation is positive and significant effect of job satisfaction, has not proved so unacceptable

$\mathrm{H}_{2}$ : Supported by empirical data so that the research hypothesis which states that the leadership style positive and significant impact on job satisfaction, proved unacceptable

$\mathrm{H}_{3}$ : Supported by empirical data so that the research hypothesis which states that Competency positive and significant impact on job satisfaction, proved unacceptable

$\mathrm{H}_{4}$ : Supported by empirical data so that the research hypothesis which states that work motivation is positive and significant effect on the performance of employees, proven acceptable

$\mathrm{H}_{5}$ : Supported by empirical data so that the research hypothesis which states that leadership style is positive and significant effect on the performance of employees, proven acceptable

$\mathrm{H}_{6}$ : Rejected by empirical data so that the research hypothesis which states that Competency positiveinfluence and significant employee performance, has not proved so unacceptable

$\mathrm{H}_{7}$ : Supported by empirical data so that the research hypothesis which states that job satisfaction positive and significant effect on the performance of employees, proved unacceptable

$\mathrm{H}_{8}$ : Supported by empirical data so that the research hypothesis which states that the motivation of work through job satisfaction positive and significant effect on the performance of employees, proven acceptable

$\mathrm{H}_{9}$ : Supported by empirical data so that the research hypothesis which states that the style of leadership through job satisfaction positive and significant impact on the performance of employees, proven acceptable

$\mathrm{H}_{10}$ : Rejectedby empirical data so that the research hypothesis which states that the competence through job satisfaction and a significant positive effect on employeeperformance,t idak proved so unacceptable 


\section{Conclusion}

Based on the Research problems and hypothesis, the conclusions of this study are:

1. Employee motivation is negative and significant effect on job satisfaction. Application of motivation in the form of existence, connectivity and growth is still low, but the motivation needed to improve employee job satisfaction;

2. Leadership style has a positive and significant effect on job satisfaction. Application of leadership style has been actualized by the leadership in improving employee satisfaction;

3. Competence has a positive and significant effect on job satisfaction. Competency of employees is now actualized in accordance with the demands of routine work in improving employee satisfaction;

4. Employee motivation has a positive and significant effect on employee performance. Work motivation is very important in encouraging, supporting and encouraging employees to improve performance;

5. Leadership style has a positive and significant effect on employee performance. The leadership style of a leader capable of directing, mobilizing and influencing employees to improve employee performance;

6. Competence has a positive and insignificant effect on employee performance. Competence employee career development is still not oriented towards the development of innovation and technology in influencing employee performance improvement;

7. Job satisfaction has a positive and significant effect on employee performance. Employee in carrying out the work is able to realize feeling happy and satisfied with the job at hand to improve employee performance;

8. Employee motivation through job satisfaction has a positive and significant effect on employee performance. Application of motivation to do during this time is able to provide job satisfaction of employees to improve their performance;

9. Leadership style through job satisfaction has a positive and significant effect on employee performance. The leadership style adopted by the leader is able to meet the expected job satisfaction of employees to improve their performance; and

10. Competence through job satisfaction is positive and insignificant effect on employee performance. Application of competence directed today is still meeting the needs of the work, which leads to employee satisfaction are low in improving its performance.

\section{References}

1. Bass, Bernard M., 2010. The Future of Leadership in Learning Organizations. The Journal of Leadership Studies, 7 (3).

2. Dessler, Gerry, 2007. Appraising of Performance: ApplicationTheory. Published by John Wiley and Sons, New York.

3. -----------, 2007. Attitudes Performance Organization. Englewood Cliffs, Prentice Hall, New Jersey.

4. ----------, 2013. Human ResourceManagement. Tenth Edition. Publisher Index, Jakarta.

5. Ferdinand, Augusty, 2011. Structural Equation Modeling in Management Research. FE Diponegoro University, Semarang.

6. Hersey, Paul and Blanchard, Kenneth H, 2005. Management Organizational Behavior, Human Resources Utilizing. $4^{\text {th }}$ Ed. Englewood Cliffs, NJ, Prentice-Hall, Inc.

7. Rival, Veithzal, 2008. The Human ResourceManagement. Publisher Raja Grafindo Persada, Jakarta.

8. -------------, 2010. Leaders and Leadership in Organizations. Publisher RajawaliPress, Jakarta.

9. - ----------, 2013. Performance Appraisal. Publisher RajawaliPress, Jakarta

10. Sedarmayanti, 2008. Human Resource Management. Publisher BPFE, Yogyakarta.

11. Terry, GR., 2008. Human Resource Management. Published by McGraw Hill, Ohio.

12. Wursanto, Alim, 2003. Management WorkOrganization. Publisher Pustaka Jaya, Jakarta. 